\title{
POLITIK IDENTITAS MASYARAKAT MULTIETNIS KOTA SAWAHLUNTO DALAM PILKADA WALIKOTA DAN WAKIL WALIKOTA SAWAHLUNTO TAHUN 2018
}

\author{
Yoggi Alvi Hamdani \\ Jurusan Ilmu Politik, Fisip, Universitas Andalas \\ Email: yoggihamdani@gmail.com
}

\begin{abstract}
Abstrak
Masyarakat multietnis mendiami kawasan pusat kota dari waktu yang cukup lama dikarenakan faktor sejarah pertambangan batu bara pada masa koloni Belanda. Masyarakat multietnis Sawahlunto lebih kompleks dan bersifat konstruktif karena masyarakat memandang identitas etnis sebagai suatu hasil dari proses sosial yang kompleks. Pelaksanaan Pilkada 2018 di kota Sawahlunto menjadi catatan tersendiri ketika politik identitas etnis menjadi pengaruh atau tidaknya pada masyarakat dalam menentukan pilihan politik mereka. Pada penelitian ini menggunakan pendekatan Kualitatif dengan metode penelitian deskriptif analitis. Penelitian ini juga menggunakan teori gerakan politik etnis oleh Klause Van Beyme. Hasil penelitian menemukan kesamaan etnis yang dimiliki oleh Ismed dan masyarakat Tanah Lapang, tidak serta merta menjadikan Ismed dan Ali Yusuf dapat mendulang suara yang banyak di kelurahan Tanah Lapang. Karena itulah pelaksanaan Pemilukada Sawahlunto 2018 khususnya di kelurahan Tanah Lapang tidak menimbulkan konstelasi politik identitas dari kelompok masyarakat. Kampanye yang menggunakan atribut etnis sebagai media komunikasi politik, menimbulkan bentuk ketegangan politik pada tingkatan masyarakat. Pilkada Walikota Sawahlunto 2018 pada masyarakat multietnis Kota Sawahlunto yang tahapan kampanyenya tidak terdapat pasangan calon menggunakan isu etnisitas atau kesukuan dalam masa kampanyenya. Dalam kontestasi Pilkada Sawahlunto tahun 2018 tidak terjadi sentimen politik identitas, dimana masyarakat Sawahlunto yang multietnis terdapat suatu identitas masyarakat baru yang merupakan bagian dari ikatan solidaritas mereka.
\end{abstract}

Kata Kunci: Multietnis ; Pilkada ; Politik Identitas ; Etnis ; Sawahlunto

\begin{abstract}
The multi-ethnic community inhabited the downtown area for quite a long time due to historical factors in coal mining during the Dutch colony. The multi-ethnic Sawahlunto society is more complex and constructive because people perceive ethnic identity as a result of complex social processes. The implementation of the 2018 elections in the city of Sawahlunto becomes a special note when the politics of ethnic identity is the influence or not on the community in determining their political choices. In this study using a qualitative approach with analytical descriptive research methods. This study also uses the theory of ethnic political movements by Klause Van Beyme. The results of the study found ethnic similarities that are owned by Ismed and the Tanah Lapang community, not necessarily making Ismed and Ali Yusuf able to gain a lot of votes in the Tanah Lapang sub-district. That is why the implementation of Sawahlunto Regional Election in 2018 especially in the Tanah Lapang sub-district does not cause a political constellation of identity of the community groups. Campaigns that use ethnic attributes as a medium of political communication, create a form of political tension at the community level. Sawahlunto Mayor Election in 2018 in the multi-ethnic community of Sawahlunto City where there are no candidate pairs using ethnicity or ethnicity issues during their campaign. In the 2018 Sawahlunto regional election contestation there was no identity politics sentiment, where the multiethnic Sawahlunto community contained a new community identity that was part of their solidarity ties. Keywords: Multiethnic; Election ; Identity Politics ; Ethnicity ; Sawahlunto
\end{abstract}




\section{PENDAHULUAN}

Indonesia merupakan salah satu negara dengan bangsa di dalamnya yang kaya akan keberagaman etnis dan budaya. Namun pada awal reformasi, benih-benih perpecahan etnis di daerah mulai timbul dengan latar belakang konflik kepentingan. Seiring diberlakukan otonomi daerah, yang memberikan hak kepada setiap daerah mengatur dan memberdayakan daerah masing-masing, berdampak pada kesenjangan antar daerah karena potensi yang dimiliki tiap-tiap daerah berbeda baik dari segi sumber daya manusia maupun sumber daya alamnya. Konflik yang berlatarkan perbedaan etnis sudah sering terjadi pasca diberlakukannya otonomi daerah, seperti konflik Aceh, Papua dan Kalimantan. Masing-masing kelompok etnis menunjukkan rivalitasnya untuk mengedepankan kepentingan kelompoknya, baik dari segi ekonomi, sosial, budaya maupun politik. ${ }^{1}$

Beberapa wacana yang biasanya menjadi bahan kajian politik identitas adalah gender, agama dan bahasa, ras dan etnis. Wacana-wacana tersebut, seperti diketahui memiliki basis pembeda yang sangat jelas sekaligus memiliki kecenderungan yang besar juga untuk dimanfaatkan oleh suatu kelompok kepentingan atau wacana dominan. Namun dalam hal ini penulis akan meneliti pada ruang lingkup identitas pada etnis. Etnis atau ethnic yang dapat diartikan sebagai kesukuan atau group suku bangsa. Sedangkan dari segi bahasa Yunani, ethnos turunan dari kata ethnikos, yang berarti penyembah berhala (heathen).

Etnisitas merupakan simbol identitas yang kerap dimanfaatkan sebagai alat untuk merebut kekuasaan politik dan ekonomi. Terdapat dua argumen dasar yang melandasi hal ini: pertama, setiap pemilihan pemimpin seperti pemilihan Presiden dan pemilihan kepala daerah (Pilkada) yang dilaksanakan dalam lima tahun sekali, isu tentang asal etnis (geopolitik) kandidat tidak akan terlepas dari kerangka pertarungan politik antara kandidat. Kedua, penguasaan dan akses terhadap aset-aset ekonomi oleh entitas sosial tertentu, juga tidak pernah lepas dari bahan pembicaraan dari para kalangan intelektual sosial dan politikus sampai kepada masyarakat biasa. ${ }^{2}$

Peneliti melihat kelompok masyarakat yang memiliki komposisi etnis yang beragam (multietnis) masyarakat tersebut adalah masyarakat Kota Sawahlunto, yang pada awal berdirinya Kota Sawahlunto terkenal sebagai kota tambang batubara, yang jumlah produksi batubara Kota Sawahlunto merupakan yang terbesar kedua pada Tahun 1990an. Kota Sawahlunto pada awalnya merupakan bagian dari kabupaten Sijunjung yang mengalami pemekaran menjadi kotamadya Sawahlunto pada Tahun 1990, Kota Sawahlunto sebelumnya berada dalam kelarasan Koto VII Kenagarian Kubang, tetapi keberadaan tambang batubara memindahkan pusat unit pemerintahan terendah mereka

\footnotetext{
${ }^{1}$ Dedi Firmansyah , Peran Politik Etnis dalam Pilkada (Studi atas Pilgub Provinsi Bengkulu tahun 2005). Skripsi tahun 2010 hal 1

${ }^{2}$ Imam Mujahidin Fahmid, Identitas Dalam Kekuasaan. (2012), hal 1
} 
aspiran controller, wakil controller dari Silungkang ke Sawahlunto. ${ }^{3}$ Pada Tahun 1990 kota ini mengalami perluasan wilayah dari Kecamatan Lembah Segar sebagai pusat kota lama menjadi Kecamatan Talawi dan Kecamatan Silungkang sebagai kecamatan baru yang sebelumnya berada dalam kabupaten Sijunjung. Terdapat dua identitas ganda di Kota Sawahlunto, diantaranya identitas "Kota lama" dan "kota baru". 4

Hal menarik yang peneliti temui pada masyarakat multietnis di Kota Sawahlunto, khususnya pada kecamatan Lembah Segar adalah bagaimana masyarakat bersama-sama melebur dalam kehidupan masyarakat sosial dan menghasilkan suatu identitas masyarakat baru dengan nama "masyarakat Tangsi". Keanekaragaman etnisitas pada masyarakat di kecamatan lembah segar juga berdampak pada kehidupan politik masyarakat yang multietnis dalam hal pemilu khususnya Pilkada Walikota dan Wakil walikota kota Sawahlunto baru-baru ini.

Bentuk harmonisasi kehidupan masyarakat multietnis kota Sawahlunto dengan identitas baru mereka tergambar dalam acara makan bajamba yang menjadi acara rutin tiap ulang tahun Kota Sawahlunto. Prosesi makan bajamba menjadi puncak peringatan hari jadi Kota Sawahlunto ke-130, Sabtu, 1 Desember 2018 menjadi pesta rakyat Sawahlunto. Berbagai etnis, suku, budaya dan agama melalui paguyuban paguyuban masing masing termasuk para perantau berbaur jadi satu memeriahkan hari lahirnya Sawahlunto. Diawali dengan sidang Paripurna Istimewa DPRD setempat, Ketua LKAAM membacakan napak tilas berdirinya "Kota Arang" tercinta.

Salah satu paguyuban yang terlibat dalam makan bajamba itu, yakni paguyuban Batak "Dis Ni Roha" yang setiap tahunnya ikut meramaikan tradisi tersebut. Ketua Paguyuban Batak Sawahlunto El Sihotang mengatakan keikutsertaan paguyuban merupakan bentuk kebersamaan dan kebahagiaan karena telah menjadi bagian dari sejarah dan keberagaman dikota ini. "Kecintaan kami kepada kota ini, salah satunya dengan ikut dalam setiap pembangunan dan event yang digelar oleh Pemko setempat," ujarnya. Selain itu lanjutnya, paguyuban Dis Ni Roha aktif berpartisipasi pada event Sawahlunto Multicultural Festival, yang digelar dalam menyemarakkan hari jadi Kota Sawahlunto setiap tahunnya. ${ }^{5}$

Dalam hal kehidupan berpolitik, masyarakat Kota Sawahlunto memiliki keikutsertaan yang sangat aktif meskipun dalam skop terkecil pemerintahan seperti di skala rukun tetangga dan rukun warga (RT/RW). Setiap warga memiliki hak dan kewajiban yang sama, meskipun ada masyarakat yang berasal dari etnis yang menjadi

\footnotetext{
${ }^{3}$ Gede Budi Suprayoga, “Identitas Kota Sawahlunto Paska Kejayaan Pertambangan Batubara”, Jurnal Perencanaan Wilayah dan Kota, Vol. 19, 2008, hal 2

${ }^{4}$ Ibid

${ }^{5}$ Lihathttps://www.harianhaluan.com/news/detail/72263/makan-bajamba-di-sawahlunto-tradisimeyatukan-keberagaman diakses pada tanggal 23-05-2019
} 
golongan minoritas. Hal ini dibuktikan dari hasil wawancara dengan salah satu ketua RW, Desa Air Dingin dengan ungkapan sebagai berikut :

"Untuk di Tangsi sini, kami kan asalnya beragam etnis, ada yang Jawa, Minang, Batak, Sunda bahkan Cina. Jadi disini kami dalam pemilihan ketua RW itu dengan cara mendatangi tiap tiap rumah dan memberikan amplop kosong per orang yang sudah ada hak pilih dalam satu rumah tersebut. Jadi misal dirumah A ada lima orang yang milih berarti lima amplop, amplop tersebut berguna untuk menampung nama dari pemilih yang dirasa cocok untuk menjadi ketua RW. Karena disini kami tidak ada calon dalam pemilihan RW, warga bebas memilih siapa saja, bahkan bisa memilih diri sendiri. Meskipun disini yang mayoritasnya adalah Jawa dan Minang, ketua RW tidak selalu orang Jawa dan Minang, etnis tidak ada pengaruhnya disini karena kami disini sudah menjadi masyarakat Tangsi."

Hal lain yang menjadi perhatian peneliti pada masyarakat multietnis Kota Sawahlunto dalam hal pemilu adalah tidak adanya intervensi dari tokoh masyarakat masing masing etnis dalam hal menentukan pilihan politiknya, masyarakat bebas menentukan pilihan meskipun memiliki latar belakang etnis yang berbeda. Hal ini disampaikan dalam wawancara peneliti dengan tokoh Jawa di kecamatan Lembah Segar yang bernama Tagor, dengan ungkapannya sebagai berikut;

"Kami disini tidak ada mengarahkan masyarakat untuk memilih calon walikota dengan melihat sukunya, warga bebas memilih pilihannya dengan pertimbangan masingmasing. Saya selaku yang dituakan disini sebagai tokoh Jawa dan teman-teman dari suku lain tidak pernah melakukan ajakan kepada masyarakat untuk memilih berdasarkan kesamaan suku." 7

Interaksi masyarakat multietnis di Kota Sawahlunto tercermin dalam segala aspek bidang kehidupan sehari-hari yang menjadi hal menarik untuk diteliti lebih dalam lagi. Terutama dalam aspek kehidupan berpolitik masyarakat Kota Sawahlunto yang baru baru ini telah mengadakan pemilihan umum (Pemilu) Walikota dan Wakil Walikota periode 2018-2023.

Agar penelitian ini menjadi terarah dan ruang lingkup tidak terlalu luas maka berdasarkan uraian latar belakang penelitian di atas, permasalahan yang diteliti secara rinci adalah: Bagaimana pengaruh politik identitas dalam Pemilukada Walikota dan Wakil walikota Sawahlunto tahun 2018.

\section{Konsep Politik Identitas}

Identitas menurut Jeffrey Week adalah berkaitan dengan belonging tentang persamaan dengan sejumlah orang dan apa yang membedakan seseorang dengan yang lain. Pendapat Jeffrey Week tersebut menekankan pentingnya identitas bagi tiap individu

\footnotetext{
${ }^{6}$ Wawancara dengan Ketua RW 02, Desa Tangsi tanggal 24 Februari 2019 di Kecamatan Lembah Segar ${ }^{7}$ Wawancara dengan Sinaga (salah satu tokoh masyarakat di kecamatan lembah segar) tanggal 23 Februari 2019 di Kecamatan Lembah Segar
} 
maupun bagi suatu kelompok atau komunitas ${ }^{8}$. Namun demikian, sebenarnya akan lebih mudah bila kita memahami konsep identitas ini dalam bentuk contoh. Ketika seseorang lahir, ia tentu akan mendapatkan identitas yang bersifat fisik dan juga non-fisik. Identitas fisik yang terutama dimiliki adalah apakah ia berjenis kelamin pria atau wanita. Sedangkan untuk identitas non-fisik adalah nama yang digunakan, juga status yang ada pada keluarga pada saat dilahirkan.

Identitas dalam sosiologi maupun politik biasanya dikategorikan menjadi dua kategori utama, yakni identitas sosial (kelas, ras, etnis, gender, dan seksualitas) dan identitas politik. Identitas sosial menentukan posisi subjek di dalam relasi atau interaksi sosialnya, sedangkan identitas politik menentukan posisi subjek di dalam suatu komunitas melalui suatu rasa kepemilikan (sense of belonging) dan sekaligus menandai posisi subjek yang lain di dalam suatu perbedaan (sense of otherness) ${ }^{9}$. Identitas politik (politics identity) secara konseptual berbeda dengan "politik identitas" (politics of identity). Identitas politik merupakan konstruksi yang menentukan posisi kepentingan subjek di dalam suatu ikatan komunitas politik, sedangkan pengertian politik identitas mengacu pada mekanisme politik pengorganisasian identitas (baik identitas politik maupun identitas sosial) sebagai sumberdaya dan sarana politik ${ }^{10}$. Secara sederhana, apa yang dimaksud identitas didefinisikan sebagai karakteristik esensial yang menjadi basis pengenalan dari sesuatu hal. Identitas merupakan karakteristik khusus setiap orang atau komunitas yang menjadi titik masuk bagi orang lain atau komunitas lain untuk mengenalkan mereka. ${ }^{11}$ Ini adalah definisi umum yang sederhana mengenai identitas dan akan kita pakai dalam pembahasan berikutnya mengenai politik identitas.

\section{Pendekatan Teoritis Dalam Melihat Etnisitas}

(1)Pendekatan primordialisme melihat fenomena etnis dalam kategori-kategori sosio-biologis. Pendekatan ini umumnya beranggapan bahwa kelompok-kelompok sosial dikarakteristikan oleh gambaran seperti kewilayahan, agama, kebudayaan, bahasa dan organisasi sosial yang memang disadari secara objek sebagai hal yang "given" dari sananya, dan tidak bisa dibantah. Pendekatan ini terbukti mempunyai pengaruh terhadap gambaran sosial masyarakat. (2) Pendekatan konstruktivisme dikembangkan oleh Frederich Barth yang memandang identitas etnis sebagai suatu hasil dari proses sosial yang kompleks, manakala batasan-batasan simbolik terus-menerus membangun dan dibangun oleh manfaat mitologi, suatu hitungan sejarah dari bahasa dan pengalaman masa lampau. Pendekatan ini melihat munculnya etnis dari proses sosial yang tujuannya untuk membangun dan mengarah pada suatu perbaikan. Namun untuk melihat realita etnis di Sawahlunto, peneliti mencoba menganalisis apakah konstruksi sosial yang dilakukan oleh

\footnotetext{
${ }^{8}$ Cin Pratipa Hapsarin, Ibid h 6

9 Setyaningrum, Arie. Jurnal Mandatory Politik Perlawanan: Memetakan Lokasi bagi 'Politik Identitas' dalam Wacana Politik Poskolonial. Yogyakarta

${ }^{10}$ Ibid hal 19

${ }^{11}$ Widayanti, Titik. 2009. Politik Subalter: Pergulatan Identitas Waria. UGM. Yogyakarta. hal 13
} 
kelompok tertentu tersebut bertujuan membangun konsep etnis untuk perbaikan atau hanya untuk kepentingan sesaat yaitu kekuasaan politik. (3) Pendekatan instrumentalisme menaruh perhatian pada proses manipulasi dan mobilisasi politik yang manakala kelompok sosial tersebut tersusun atas dasar atribut awal etnisitas seperti kebangsaan, ras dan bahasa. pendekatan ini melihat kelompok etnis dalam suatu populasi yang mempunyai nilai budaya yang sama dan sadar akan kebersamaannya dalam bentuk budaya, membentuk jaringan komunikasi serta menentukan ciri kelompoknya sendiri. ${ }^{12}$

\section{Implementasi Politik Etnis}

Klause Van Beyme menganalisis dan mencoba melihat wacana gerakan sosial politik yang didasarkan atas politik etnis dalam beberapa tahap perkembangannya mulai era pra modern, modern, dan postmodern. Dimana Ia menggambarkan pola-pola gerakan, motivasi, dan tujuan yang hendak dicapainya maka ia mengungkapkan sebagai berikut: ${ }^{13}$

Tabel 1. Pola Politik Identitas Etnis

\begin{tabular}{llll}
\hline Model Teori & \multicolumn{1}{c}{ Pola Keterangan } & Pola Aksi & \multicolumn{1}{c}{$\begin{array}{c}\text { Tujuan } \\
\text { Gerakan }\end{array}$} \\
\hline Pra Modern & $\begin{array}{l}\text { Perpecahan Objektif (dimana ada } \\
\text { perpecahan fundamental pasti ada } \\
\text { gerakan sosial yang menyeluruh) }\end{array}$ & $\begin{array}{l}\text { Mobilisasi secara } \\
\text { ideologis atas } \\
\text { inspirasi pemimpin }\end{array}$ & $\begin{array}{l}\text { Perampasan } \\
\text { Kekuasaan }\end{array}$ \\
Modern & $\begin{array}{l}\text { Pendekatan Kondisional } \\
\text { (keterpecahan membutuhkan } \\
\text { sumber-sumber untuk } \\
\text { dimobilisasi). }\end{array}$ & $\begin{array}{l}\text { Keseimbangan } \\
\text { mobilisasi dari atas } \\
\text { dan partisipasi dari } \\
\text { Postmodern }\end{array}$ & $\begin{array}{l}\text { Pembagian } \\
\text { Kekuasaan }\end{array}$ \\
& $\begin{array}{l}\text { Gerakan tumbuh dari } \\
\text { dinamikanya sendiri. Protes } \\
\text { muncul dari berbagai macam } \\
\text { kesempatan individual. Tidak } \\
\text { terdapat satu pecahan yang } \\
\text { dominan. }\end{array}$ & Kesadaran diri & Otonomi \\
\hline
\end{tabular}

Kategorisasi gerakan politik etnis yang dipaparkan oleh Van Beyme di atas dapat diterapkan dalam menganalisis implementasi pola- pola gerakan politik etnis. Wacana politik etnis pada tahap pra modern merupakan kelompok-kelompok yang terpecah berdasarkan nasionalisme etnis yang kental, belum mengenal kebudayaan, dalam arti mengenal sesuatu dengan apa adanya. Tujuan dari gerakan politiknya adalah kekuasaan atau dominasi atas kelompok etnis yang lain, hal ini dilakukan untuk produksi demi kelangsungan hidup (tribalisme). Peran pemimpin dalam proses ini sangat dominan,

\footnotetext{
12 Alexsander Yandra, Op cit hal 9

${ }^{13}$ Ibid
} 
paternalisme memegang peran penting dalam pembentukan komunitas dan masyarakatnya sebagai sebuah koloni.

Klause Von Beyme membuat karakteristik daripada pola gerakan politik identitas yaitu pertama, gerakan politik identitas yang pada dasarnya membangun kembali narasi besar yang prinsipnya mereka tolak dan membangun suatu teori yang mengendalikan faktor-faktor biologis sebagai penyusun perbedaan-perbedaan mendasar dalam realitas kehidupannya. Kedua, dalam gerakan politik identitas ada kecenderungan tertentu untuk membangun system reversed apartheid. Ketika kekuasaan tidak dapat ditaklukan dan power sharing tidak tercapai sebagai tujuan gerakan, maka pemisahan atau autonomi dan pengecualian diri dijadikan solusi. Secara histori, menurut Beyme wacana gerakan sosial politik yang didasarkan pada pola politik identitas dapat di bahagi melalui tiga kategori, yaitu pertama, era pra modern, di mana wacana politik identitas etnis merupakan kelompok-kelompok yang terpecah berdasarkan nasionalisme etnis, belum mengenal kebudayaan. ${ }^{14}$ Tujuan daripada gerakan politiknya adalah kekuasaan dan dominasi atas kelompok etnis lainnya demi untuk kelangsungan hidupnya (tribalism). Peran pemimpin dalam proses ini sangat penting dan dominan. Paternalisme memegang peran yang sangat penting dalam pembentukan komuniti dan masyarakatnya.

Kedua, era moden, di mana gerakan politik identitas peran pemimpin tidak lagi dominan, kerana sudah diikuti oleh peran dan keikutsertaan dari akar umbi yang akhirnya menghala pada pembagian kekuasaan. Pada fase ini pula sudah muncul ideologi, dan peran-peran besar modernisasi. Sedangkan yang ketiga, era postmodern, di mana gerakan politik identitas ditandai dengan keterpecahan kelompok-kelompok etnis dalam berbagai bentuk, pola dan struktur budaya saling memperlihatkan dirinya.

\section{METODE PENELITIAN}

Penelitian ini menggunakan pendekatan kualitatif, yang mana penelitian kualitatif ini memecahkan masalah yang masih bersifat sementara, tentatif dan akan berkembang atau berganti setelah peneliti berada di lapangan, berupa kejadian/fenomenal/gejala sosial adalah makna dibalik kejadian tersebut yang dapat dijadikan pelajaran berharga bagi suatu pengembangan konsep atau teori. ${ }^{15}$

Jenis metode penelitian yang dipilih adalah deskriptif analitis, adapun pengertian dari metode deskriptif analitis menurut Sugiono adalah suatu metode yang berfungsi untuk mendeskripsikan atau memberi gambaran terhadap objek yang diteliti melalui data atau sampel yang telah terkumpul sebagaimana adanya tanpa melakukan analisis dan membuat kesimpulan yang berlaku untuk umum. Dengan kata lain penelitian deskriptif analitis mengambil masalah atau memusatkan perhatian kepada masalah-masalah sebagaimana adanya saat penelitian dilaksanakan, hasil penelitian yang kemudian diolah

${ }^{14}$ Kristianus, Journal: unnes.ac.id, Vol 1 ( Semarang: Indonesian Political Science Review, 2016) hal 94

${ }^{15}$ Djaman Satori dan Aan Komariah, Metodologi Penelitian Kualitatif, Alfabeta, Bandung, 2013, hal 22. 
dan dianalisis untuk diambil kesimpulannya. Maka dalam penelitian ini, peneliti akan menggunakan metode deskriptif analitis untuk menjelaskan bentuk politik identitas dalam Pilkada walikota dan wakil walikota kota Sawahlunto tahun 2018.

\section{HASIL DAN PEMBAHASAN}

\section{Identitas Masyarakat Multietnis Kota Sawahlunto}

Perkembangan sosial-budaya di Kota Sawahlunto erat kaitannya dengan serangkaian kegiatan pertambangan batubara Ombilin. Perusahaan tambang dan Pemerintah Hindia Belanda telah mengerahkan tenaga kerja sejak periode awal dari berbagai daerah Hindia Belanda bahkan dari luar negeri melalui pasar tenaga kerja Singapura. Para pekerja yang didatangkan diantaranya berstatus buruh kontrak, pekerja hukuman atau paksa (orang rantai), pekerja kantoran dan para tenaga ahli yang didatangkan dari Eropa, khususnya dari Belanda. Mereka berasal berasal dari berbagai etnis suku bangsa diantaranya; Minang, Bugis, Madura, Jawa,Bali, Batak, Aceh, dan Cina. ${ }^{16}$

Mereka yang didatangkan sebagai pekerja pada perusahaan tambang atau yang datang secara mandiri ke Sawahlunto itu dari latar belakang berbagai etnis, suku bangsa yang kemudian diantara mereka tinggal atau menetap di Sawahlunto. Keberagaman latar etnis dan budaya sudah menjadi hal yang integral dalam sosial masyarakat Sawahlunto. Interaksi antar etnis terjalin melalui perkawinan, budaya, olahraga maupun organisasi. Dalam hal komunikasi antar etnis Sawahlunto direkatkan dan menjadi identitas sekaligus corak khas komunikasi masyarakat Sawahlunto melalui bahasa campuran atau yang dikenal dengan bahasa tangsi. Gesekan-gesekan sosial yang menegangkan antar atau lintas etnis hampir tidak ditemui di Sawahlunto.

Masyarakat kelurahan Tanah Lapang merupakan salah satu contoh masyarakat majemuk di Indonesia. Majemuk disini dalam artian berbeda dari asal etnis masyarakat tersebut atau yang lebih dikenal sebagai masyarakat multikultural. Masyarakat multikultural menggunakan konsep multikulturalisme yang merupakan konsep pola pikir yang menuntut kesediaan untuk menerima kehadiran kelompok dan sistem nilai lain dalam kehidupan bersama tanpa memperdulikan perbedaan budaya, stratifikasi, sosial, gender, dan agama. ${ }^{17}$

Konsep ini sejalan dengan pandangan yang menyatakan multikulturalisme sebagai ideologi yang mengakui dan mengagungkan perbedaan dan kesederajatan manusia baik sebagai individu maupun sebagai masyarakat sekaligus dengan kebudayaan. ${ }^{18}$ Dalam memahami makna multikulturalisme, budaya atau etnis dipandang

\footnotetext{
${ }^{16}$ Data BPS kota Sawahlunto "Sawahlunto Dalam Angka 2018"

${ }^{17}$ Sri Astuti Buchari, Kebangkitan Etnis menuju Politik Identitas, h.31

${ }^{18}$ Ibid hal 32
} 
sebagai proses yang dinamis dari adaptasi manusia terhadap perjalanan sejarahnya yang merupakan kondisi untuk mempertahankan kehidupan melalui keterlibatan masyarakat yang bersifat simpatik atau ikut serta secara aktif yang tergambar salah satunya pada masyarakat kelurahan Tanah Lapang.

Perkembangan budaya masyarakat multietnis di kelurahan Tanah Lapang sangat dipengaruhi oleh faktor historikal kegiatan pertambangan batubara pada zaman kolonial Belanda. Perusahaan tambang dan pemerintah kolonial Belanda telah mengerahkan tenaga kerja sejak periode awal dari berbagai daerah kolonial Belanda. Para pekerja yang didatangkan diantaranya berstatus buruh kontrak, pekerja hukuman atau paksa (orang rantai), pekerja kantoran dan para tenaga ahli yang didatangkan dari Eropa, khususnya dari Belanda. Mereka berasal berasal dari berbagai etnis suku bangsa diantaranya; Minang, Bugis, Madura, Jawa,Bali, Batak, Aceh, dan Cina.

Masyarakat Tangsi bukanlah masyarakat yang artinya mendiami daerah yang bernama tangsi namun lebih tepatnya adalah bahasa, yaitu bahasa tangsi. Tapi lama kelamaan masyarakat di kelurahan Tanah Lapang dikenal atau disebut sebagai orang tangsi. Hal itu terjadi karena kelurahan Tanah Lapang adalah dimana lahirnya bahasa Tangsi karena masyarakat disini berasal dari suku yang beragam. Seperti suku Minang, Jawa, Batak, Madura, Cina, juga dari agama yang beragam, di kelurahan Tanah Lapang, ada tiga agama yang dianut masyarakatnya yaitu Islam sebagai mayoritas dan Kristen Protestan dan Katolik sebagai minoritas.

Perkembangan budaya masyarakat multietnis di kelurahan Tanah Lapang sangat dipengaruhi oleh faktor historikal kegiatan pertambangan batubara pada zaman kolonial Belanda. Perusahaan tambang dan pemerintah kolonial Belanda telah mengerahkan tenaga kerja sejak periode awal dari berbagai daerah kolonial Belanda. Para pekerja yang didatangkan diantaranya berstatus buruh kontrak, pekerja hukuman atau paksa (orang rantai), pekerja kantoran dan para tenaga ahli yang didatangkan dari Eropa, khususnya dari Belanda. Mereka berasal berasal dari berbagai etnis suku bangsa diantaranya; Minang, Bugis, Madura, Jawa,Bali, Batak, Aceh, dan Cina.

Masyarakat Tangsi bukanlah masyarakat yang artinya mendiami daerah yang bernama tangsi namun lebih tepatnya adalah bahasa, yaitu bahasa tangsi. Tapi lama kelamaan masyarakat di kelurahan Tanah Lapang dikenal atau disebut sebagai orang tangsi. Hal itu terjadi karena kelurahan Tanah Lapang adalah dimana lahirnya bahasa Tangsi karena masyarakat disini berasal dari suku yang beragam. Seperti suku Minang, Jawa, Batak, Madura, Cina, juga dari agama yang beragam, di kelurahan Tanah Lapang, ada tiga agama yang dianut masyarakatnya yaitu Islam sebagai mayoritas dan Kristen Protestan dan Katolik sebagai minoritas.

\section{Pengaruh Politik Identitas Dalam Pilkada di Kota Sawahlunto}

Jika kita melihat kelurahan Tanah Lapang ada pemaknaan identitas kelompok etnis antara masyarakat Minang, Jawa, Batak dan Tionghoa, yang hidup secara 
berdampingan dengan harmonis dan menjadi suatu identitas masyarakat yang baru. Hal ini menarik ketika persoalan etnis tidak berpengaruh terhadap kehidupan masyarakat lokal dan politik lokal di kelurahan Tanah Lapang dalam pemilukada 2018. Masyarakat kelurahan Tanah Lapang tetap memilih siapa yang akan menjadi kepala daerah nantinya tanpa memandang persamaan suku dengan kandidat calon walikota dan wakil walikota.

Kondisi kehidupan sosial politik masyarakat multietnis Sawahlunto dalam peran memperjuangkan hak-hak sosial dan politiknya merujuk pada pendapat Gaffar tentang demokrasi yang harus sangat erat berkaitan dengan upaya pertanggungjawaban (accountability), kompetensi, keterlibatan, dan tinggi rendahnya kadar untuk menikmati hak-hak dasar, seperti berekspresi, hak untuk berserikat, berkumpul adalah satu keharusan dalam proses demokratisasi yang terjadi pada era otonomi daerah. ${ }^{19}$

Dinamika kehidupan sosial politik masyarakat multietnis kelurahan Tanah Lapang, memperlihatkan adanya perkembangan politik yang semakin meningkat dan solid. Tingkat tenggang rasa antar kelompok etnis dibangun dan dikembangkan pada kehidupan masyarakat multietnis yang tidak terlepas dari kehidupan politik demokrasi yang berlandaskan kepada konsep semangat, kerja keras, dan tenggang rasa mereka dalam mempersatukan kebersamaan dan mempererat antar sesama kelompok etnis yang ada dalam masyarakat Sawahlunto. Meskipun masyarakat di kelurahan Tanah Lapang yang mayoritasnya adalah orang yang berasal dari suku Minang dan Jawa, tidak membuat hal tersebut dimanfaatkan oleh tokoh masyarakat Minang dan Jawa untuk menjadi alasan mengarahkan memilih pasangan walikota berdasarkan kesamaan etnis/suku.

Pilkada 2018 kota Sawahlunto menjadi salah satu bukti dari gerakan politik identitas masyarakat yang tergolong era postmodern. Gerakan etnis tidak terpola pada kelompok-kelompok masyarakat dengan etnis/suku yang sama. Sehingga isu budaya tidak untuk dijadikan bahan politik memenangkan pasangan calon tertentu seperti misalnya pasangan Ali Yusuf - Ismed, yang dimana Ismed selaku wakilnya berasal dari wilayah tersebut (Tanah Lapang). Tidak adanya gerakan masyarakat yang didasarkan atas mobilisasi oleh elit politik untuk tujuan memperoleh suara terhadap masyarakat menjadikan kelompok masyarakat Tangsi menjadi masyarakat yang sudah menghilangkan sifat primor mereka. Dalam bentuk implementasi politik etnis Ubed Abdillah, pada politik etnis yang terjadi di Sawahlunto antara etnis Minang, Jawa, Batak dan Tionghoa dalam konteks Pilkada adalah model postmodern.

\section{Atribut Etnis Tidak Sebagai Instrumen Dalam Kampanye}

Masyarakat yang tidak terpengaruh oleh paham kedaerahan (primordialisme) dan menjadi cerdas dalam hal politik serta memberikan suatu perlakuan ataupun pemahaman yang membuat masyarakat untuk berpartisipasi dengan lebih mengutamakan kualitas dari apa yang menjadi tujuannya sebagai masyarakat sosial. Realitas di atas melihatkan

\footnotetext{
${ }^{19}$ Ibid hal 153
} 
bahwa, identitas yang melekat dalam tiap orang boleh saja berbeda secara etnis/suku dan agama. Namun hal itu tidak menjadi sentimen yang menghambat terbentuknya integrasi politik pada masyarakat Tanah Lapang kota Sawahlunto dengan ditunjukkan dalam struktur sosial.

Suasana kondusif yang terjadi pada tahap pelaksanaan Pilkada Sawahlunto 2018 khususnya dalam konteks kampanye seperti nihilnya laporan pelanggaran pemilu oleh Badan Pengawas Pemilu (BAWASLU) kota Sawahlunto yang bersifat non teknis. Seperti penyerangan tim sukses dan pengrusakan alat peraga kampanye salah satu paslon di kecamatan Lembah Segar, yang memperlihatkan adanya bentuk kehidupan sosial politik yang memberikan kebebasan terhadap perbedaan yang ada (pluralisme politik). Kelompok minoritas merupakan bagian dalam demokrasi secara eksistensi telah dapat mengembangkan perbedaan dengan kelompok mayoritas serta bersama - sama membentuk dan menjadi suatu kelompok dengan identitas baru. Etnis Batak dan Tionghoa sebagai kelompok minoritas merasa aman dalam khususnya dalam hal kehidupan politik seperti Pilkada Sawahlunto 2018 baru ini.

Dengan demikian fenomena politik identitas di dalam pilkada itu bukan sesuatu yang baru dan hanya milik suatu daerah tertentu, hanya saja tidak di semua daerah di Indonesia hal ini bisa muncul dan terlaksana secara efektif mencapai tujuannya. Dalam konteks masyarakat Sawahlunto, munculnya politik identitas di tengah-tengah masyarakat yang multietnis memang dijumpai, tetapi tidak dijadikan alat untuk memobilisasi masyarakat yang tujuan sebenarnya adalah mencari suara sebanyakbanyaknya dalam Pilkada kota Sawahlunto. Dalam kontestasi Pilkada Sawahlunto tidak terjadi sentimen politik identitas, dimana tidak dijumpainya seperti kasus pribumi mengkhususkan diri dan menolak non-pribumi, hal ini terkait dengan ketika kekuasaan tidak dapat ditaklukkan dan pembagian kekuasaan tidak tercapai sebagai tujuan gerakan, pengelompokkan masyarakat berdasarkan etnis diambil sebagai jalan keluar untuk menjatuhkan pasangan calon yang lain.

Klause Von Beyme membuat karakteristik daripada pola gerakan politik identitas yaitu pertama, gerakan politik identitas yang pada dasarnya membangun kembali narasi besar yang prinsipnya mereka tolak dan membangun suatu teori yang mengendalikan faktor-faktor biologis sebagai penyusun perbedaan-perbedaan mendasar dalam realitas kehidupannya. Kedua, dalam gerakan politik identitas ada kecenderungan tertentu untuk membangun system reversed apartheid. Ketika kekuasaan tidak dapat ditaklukan dan power sharing tidak tercapai sebagai tujuan gerakan, maka pemisahan atau autonomi dan pengecualian diri dijadikan solusi.

Secara histori, menurut Beyme wacana gerakan sosial politik yang didasarkan pada pola politik identitas dapat dibagi melalui tiga kategori, yaitu pertama, era pra modern, di mana wacana politik identitas etnis merupakan kelompok-kelompok yang 
terpecah berdasarkan nasionalisme etnis, belum mengenal kebudayaan. ${ }^{20}$ Tujuan daripada gerakan politiknya adalah kekuasaan dan dominasi atas kelompok etnis lainnya demi untuk kelangsungan hidupnya (tribalism). Peran pemimpin dalam proses ini sangat penting dan dominan. Paternalisme memegang peran yang sangat penting dalam pembentukan komuniti dan masyarakatnya. Kedua, era modern, di mana gerakan politik identitas peran pemimpin tidak lagi dominan, kerana sudah diikuti oleh peran dan keikutsertaan dari akar umbi yang akhirnya mengahala pada pembagian kekuasaan. Pada fase ini pula sudah muncul ideologi, dan peran-peran besar modernisasi. Sedangkan yang ketiga, era postmodern, di mana gerakan politik identitas ditandai dengan keterpecahan kelompok-kelompok etnis dalam berbagai bentuk, pola dan struktur budaya saling memperlihatkan dirinya.

Gerakan politik dan sosial pada era ini menurut Beyme bukan pada orientasi kekuasaan untuk mendominasi, namun lebih hanya pada politik kebudayaan, kepemilikan atas hak-hak sosial, autonomi, kebebasan berekspresi dan berbudaya. Kalau melihat pembagian yang dilakukan oleh Beyme, fenomena gerakan politik identitas di beberapa daerah di Indonesia dapat dikategorisasikan ke dalam satu fase saja dalam periode waktu tertentu, karena ia merupakan satu gerakan yang bersifat dinamis. Gerakan politik identitas yang terjadi pada masyarakat multietnis Sawahlunto pada Pilkada Sawahlunto tahun 2018 merupakan post modern. keadaan ini terlihat di mana tujuan gerakan politiknya ingin memperoleh hak-hak sosial, dan ekonomi yang lebih baik. Cara-cara untuk memperoleh kekuasaan dan hak-hak tersebut dalam prakteknya juga dilakukan dengan tidak menggunakan atribut etnis dalam memobilisasi masyarakat. Peran pemimpin atau elit lokal sangat dominan dalam proses gerakan politik identitas tersebut.

Pilkada 2018 kota Sawahlunto menjadi salah satu bukti dari gerakan politik identitas masyarakat yang tergolong era postmodern menurut klasifikasi Beyme. Gerakan etnis tidak terpola pada orientasi kekuasaan untuk mendominasi, namun lebih hanya pada politik kebudayaan, kesamaan atas hak-hak sosial, kebebasan berekspresi dan berbudaya. Sehingga isu budaya tidak untuk dijadikan bahan politik memenangkan pasangan calon tertentu seperti misalnya pasangan Ali Yusuf - Ismed, yang dimana Ismed selaku wakilnya berasal dari wilayah tersebut (Tanah Lapang). Tidak adanya gerakan masyarakat yang didasarkan atas mobilisasi oleh elit politik untuk tujuan memperoleh suara terhadap masyarakat menjadikan kelompok masyarakat Tangsi menjadi masyarakat yang sudah menghilangkan sifat primor mereka. Dalam bentuk klasifikasi gerakan politik identitas oleh Klause Van Beyme, gerakan politik identitas etnis yang terjadi pada Pilkada kota Sawahlunto antara etnis Minang, Jawa, Batak dan Tionghoa dalam konteks Pilkada adalah model postmodern.

\footnotetext{
${ }^{20}$ Kristianus, Journal: unnes.ac.id, Vol 1 ( Semarang: Indonesian Political Science Review, 2016) hal 94
} 
Dalam suatu tatanan masyarakat sosial yang multietnis, identitas budaya etnis dalam politik tidak hilang, dan biasanya melarut dalam berbagai lembaga politik yang ada. Kondisi ini mendorong gerakan penguatan etnis yang berorientasi politik. Selama pemerintahan nasional dan daerah menjalankan pelayanannya dan mengalokasikan sumberdaya yang ada secara adil maka gerakan etnis tidak terlalu menimbulkan gejolak konflik. Namun manakala ada perlakuan yang tidak adil, hak-hak sosial dan politik terabaikan serta kepentingan kelompok tidak dapat diakomodasi, maka pemimpinpemimpin kelompok tersebut berjuang untuk memperoleh hak dan sumberdaya yang adil, dan pada masa yang sama etnis akan wujud sebagai instrumen untuk mencapai tujuan sosial, ekonomi dan politiknya yang berbeda dengan budaya yang semestinya.

\section{KESIMPULAN}

Setelah menelaah panjang lebar melalui kajian lapangan (research) pada penelitian ini, maka dapat ditarik kesimpulan bahwa masyarakat Tanah Lapang lebih kompleks dan bersifat konstruktif karena masyarakat multietnis di kelurahan Tanah Lapang memandang identitas etnis sebagai suatu hasil dari proses sosial yang kompleks. Perkembangan budaya masyarakat multietnis di kelurahan Tanah Lapang sangat dipengaruhi oleh faktor historikal kegiatan pertambangan batubara pada zaman kolonial Belanda diantaranya Minang, Bugis, Madura, Jawa,Bali, Batak, Aceh, dan Cina.

Penelitian ini menemukan bahwa pada masyarakat Sawahlunto yang multietnis terdapat suatu identitas masyarakat baru yang merupakan bagian dari ikatan solidaritas mereka. Penelitian ini juga menegaskan sejarah terbentuknya identitas baru pada masyarakat multietnis di Kota Sawahlunto yang terjadi akibat aktifitas pertambangan yang dibuka oleh kolonial Belanda pada abad ke-18. Selain itu hal menarik yang ditemui dalam penelitian ini adanya harmonisasi dalam konteks interaksi pra dan pasca Pilkada Walikota Sawahlunto tahun 2018. Pengaruh politik identitas etnis dalam konteks Pilkada Walikota Sawahlunto tahun 2018 tidak mempengaruhi masyarakat serta berbagai bentuk atribut etnis tidak menjadi instrumen kampanye yang menimbulkan perpecahan dalam kehidupan sosial politik masyarakat multietnis kota Sawahlunto.

Pada Pilkada kota Sawahlunto tahun 2018, gerakan politik identitas masyarakat yang tergolong kepada era postmodern. Gerakan etnis yang tidak terpola pada kelompokkelompok masyarakat dengan etnis/suku yang sama. Sehingga isu budaya tidak untuk dijadikan bahan politik memenangkan pasangan calon tertentu. Tidak adanya gerakan masyarakat yang didasarkan atas mobilisasi oleh elit politik untuk tujuan memperoleh suara terhadap masyarakat, menjadikan kelompok masyarakat Tangsi menjadi masyarakat yang sudah menghilangkan sifat primor mereka. 


\section{DAFTAR PUSTAKA}

Abdilah S, Ubed. 2002. Politik Identitas Etnis: Pergulatan Tanda Tanpa Identitas. Yayasan Indonesiatera. Magelang.

Alexander yandra, Politik Etnisitas Dalam Pemilukada (Studi Kasus Dalam Pelaksanaan Pemilukada Bupati Dan Wakil Bupati Di Pasaman Provinsi Sumatera Barat) diakses pada tanggal 8 Juni 2019

Buchari, Sri Astuti. 2014. Kebangkitan Etnis Menuju Politik Identitas. Yogyakarta. Yayasan Obor Indonesia

Budiarjo, Miriam. 2007. Dasar-dasar Ilmu Politik. Jakarta. Gramedia Pustaka Utama

Bungin, Burhan. 2006. Metode Penelitian Kualitatif. Jakarta. Rajawali Pers.

Dedi Firmansyah. 2016. Peran Politik Etnis dalam Pilkada (Studi atas Pilgub Provinsi Bengkulu tahun 2005) Skripsi dari Fakultas Syariah, UIN Sunan Kalijaga Yogyakarta

Efriza. 2012. Political Explore. Bandung. Penerbit Alfabeta Bandung

Eunjung Choi dan Jongseok Woo. Warisan dan Makna Konfusianisme. Jurnal Internasional Korea Observer 201 Vol 49 No 3 Hal 493-513

Gaffar, Affan. 1999. Sistem Politik Indonesia. Yogyakarta. Pustaka Belajar

Gede Budi Suprayoga, "Identitas Kota Sawahlunto Paska Kejayaan Pertambangan Batubara”, Jurnal Perencanaan Wilayah dan Kota, Vol. 19, 2008, hal 2

http://www.kongres.kebudayaan.id/kota-sawahlunto/

Irfan Zharfandy. 2016. "Pengaruh Politik Identitas Terhadap Pemilihan Gubernur Sulawesi Selatan Tahun 2013" Skripsi dari FISIP Universitas Islam Negri Syarif Hidayatullah

Kristianus. 2016. "Politik dan Strategi Budaya Etnik dalam Pilkada Serentak di Kalimantan Barat". Journal Indonesian Political Science Review Vol 1 No 1, Hal 87-101

Makan bajamba di Sawahlunto, Tradisi menyatukan Keberagaman di akses dari https://www.harianhaluan.com/news/detail/72263/makan-bajamba-di-sawahluntotradisi-meyatukan-keberagaman

Maksudi, Beddy Iriawan. 2012. Sistem Politik Indonesia. Jakarta. PT Raja Grafindo Persada

Mamang Etta Sungadji dkk, 2010. Metodologi Penelitian. Yogyakarta. CV Andi Offset.

Manauwarah. 2011. Politik Etnis Masyarakat Pendatang Di Kota Palopo Skripsi dari FISIP Universitas Hasanuddin. 
Marzuki. 2005. Metodologi Riset, Panduan Penelitian Bidang Bisnis dan Sosial, Ekonisia, Yogyakarta.

Moleong, Lexy J. 2014. Bandung. Metodologi Penelitian Kualitatif. PT. Remaja Rosdakarya.

Novanda, Galuh Dwi. 2018. Unsur SARA dalam Kampanye: Sebuah Studi Komparasi Pilkada Sumatera Utara dan DKI Jakarta. Journal Seminar Nasional Hukum: Universitas Negeri Semarang Vol 4 No 3 Tahun, hal 563-580

Oana-Andreea dan Ghita-Pirnuta. 2017. Budaya Politik dan Keamanan Diberikan Sebagai Konsep Budaya: Budaya Politik Amerika. Jurnal Politik Universitas Brasov, Transylvanua, hal 75-95

Partisipasi memilih masyarakat Sawahlunto tertinggi, di akses dari http://padek.co.id/partisipasipemilihsawahluntotertinggi

Safrudin, Darmawan Purba. 2017. Analisis Orientasi, Sikap, Pilihan, dan Budaya Politik Pemuda-Pemudi Etnis Lampung Era Kontemporer. Jurnal Analisis Sosial Politik. 1 (1): 52-73.

Satori, Djam'an. 2009. Metode Penelitian Kualitatif . Bandung. Alfabeta.

Sawahlunto, Pesona Wisata Kota Tua Multietnik di akses dari https: //www.viva.co.id/foto/gaya-hidup/19305-sawahlunto-pesona-wisata-kota-tuamultietnik

Setyaningrum, Arie. Jurnal Mandatory Politik Perlawanan: Memetakan Lokasi bagi 'Politik Identitas' dalam Wacana Politik Poskolonial. Yogyakarta.

Silviu Petru dan Grecu. 2015. Budaya Politik dan Perkembangan Demokrasi di Eropa Timur. Jurnal Politik Internasional Institut Eropa Timur dan Tengah Vol 40 No 1

Sugiyono. 2016. Bandung. Metode Penelitian Kuantitatif, Kualitatif, R\&D. Alfabeta.

Thomas denk, Henrik Serup Chistenses, dan Daniel bergh. 2015. Komposisi Budaya politik Sebuah Studi Dari 25 Demokrasi di eropa. Journal Studi dalam pengembangan internasional komparatif 50 (3): 258-377.

Widayanti, Titik. 2009. Politik Subaltern: Pergulatan Identitas Waria. UGM. Yogyakarta

Yin, Robert K. 2008, Studi Kasus (Desain dan Metode). Jakarta: PT Raja Grafindo Persada. 